\title{
Broiler performance response to anise seed powder supplementation
}

\author{
H.N. Mohammed \\ Department of Animal Sciences, College of Agricultural Sciences, University of Sulaimani, Sulaimani, Iraq \\ hemin.mohammed@univsul.edu.iq
}

(Received May 21, 2018; Accepted August 14, 2018)

\begin{abstract}
The present study was conducted to evaluate growth promoting effect of anise seed Pimpinella anisum L. in broiler chickens in terms of live body weight, carcass characteristics (traits), organ weights, production traits and mortality percentage. For this purpose, four levels with $0,0.3,0.6$ and $0.9 \%$ of aniseed powder were administered in feed from day 0 till the end of experiment (42 days of age). Positive results were obtained specially in body weight and carcass traits like dressing percentage, when aniseed was fed by broiler chicken. This study showed a significant at $\mathrm{P}<0.05$ effect of different treatments on live body weight and dressing percentage, but there was no significant at $\mathrm{P}<0.05$ effects of different treatments on mortality percentage. Also, there was a significant at $\mathrm{P}<0.05$ effect of different treatments on Carcass cuts: breast, thigh and back percentage, but there was no significant at $\mathrm{P}<0.05$ effects of different treatments on wings, heart, liver and gall bladder percentage. According to the results obtained of this study, it can be concluded from this study that additive dietary broiler chicken with anise seed improve production traits like live body weight, body weight gain, dressing percentage, FCR and production index. However, there were not significant effect on mortality and some internal body organ percentage.
\end{abstract}

Keywords: anise seed, broiler performance, carcass trait, dressing percentage.

Available online at http://www.vetmedmosul.com

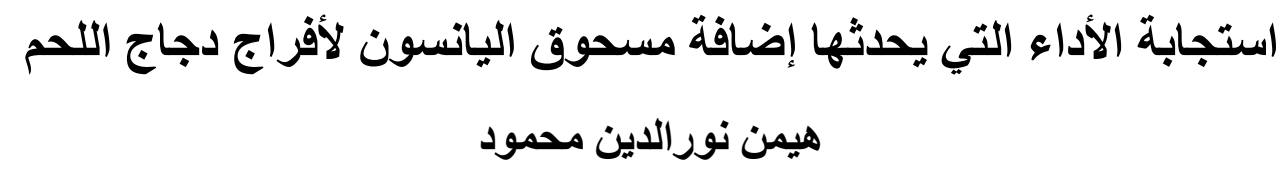

فرع علوم الحيوان، كلية الزراعة، جامعة السليمانية، السليمانية، العر اق

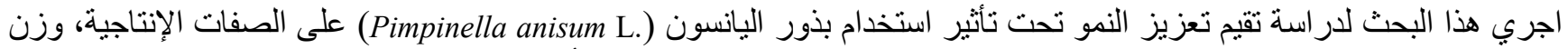

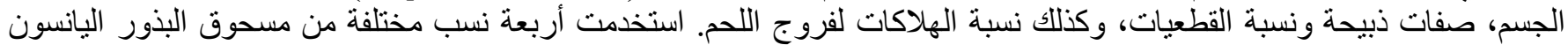

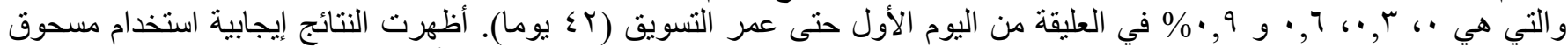

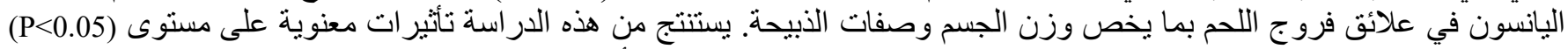

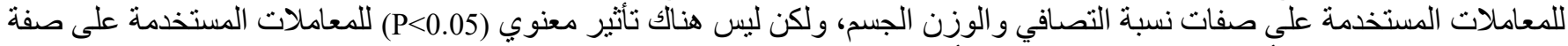

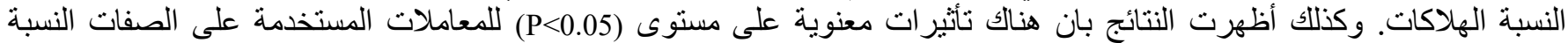

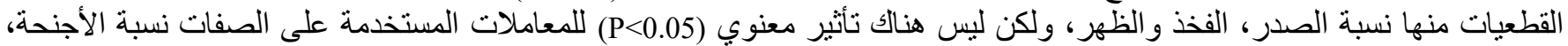

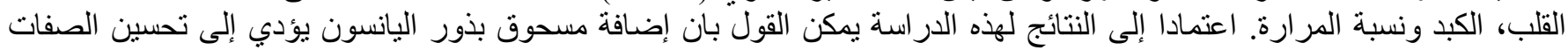

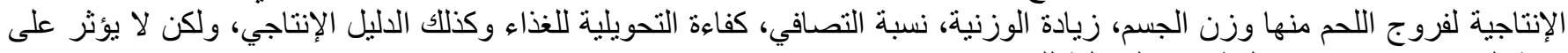

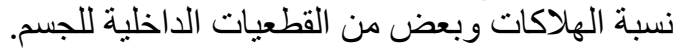

\section{Introduction}

Anise seed Pimpinella anisum L. is an aromatic plant mostly found in many countries. Aniseed essential oil contains as active ingredient anethole, methylchavicol, eugenol, anisaldehyde and estragole. Aniseed, are used to enhance the function of digestive system and it can be administered for deworming purposes (1), antimicrobial 
(2), antifungal (3) and antipyretic (4). Resultantly, the aromatic plants, herbs and their essential oils have become more important due to their multiple functions including antioxidants, antiplatelet, antitumor and immunestimulating properties (5-7).

Many researchers mentioned that Anise has 90\% anethole and aldehyde which play a role as antifungal (810). Anise anethole has many activities as antifungal, antibacterial, antiviral, antioxidant, expectorant, antispasmodic, carminative, diaphoretic properties beside digestive system stimulation and diuretic stimulate (11), Anise also has Tyrosinase inhibitory activity which play as antifungal and antibacterial agent (12). In canned food Anise used as a preservative material to increase their halflife and in human medicine anise used for kidney failure treatment (13). Anise stimulates digestive system, appetizer by increasing digestibility of nutrients by increase digestible enzymes secretion and develop hepatic activity (11,14-16). Pods of anise contain chemical compounds called shikimic acid (17). Which is used to manufacture Tamiflue that treat Bird and Swine influenza cited in (16) Shikimic acid is aneurominidase inhibitor which slows the interval spread of all viruses.

Main advantage of using anise seeds over antibiotics is that they do not bear any risk regarding bacterial resistance or undesired residues in poultry products. Anise Pimpinella anisum $\mathrm{L}$. is an aromatic annual herb widely grown in the Mediterranean region. The part used is the fruit, or the socalled seeds. Anise seeds have a number of active compounds, particularly volatile oil $1-4 \%$, which consists of largely trans-anethol $70-90 \%$ with estragole (methylchavicol), anisealdehyde, bcaryophlline, anise ketone (methyloxyphenylacetone) and the polymers of anethole (10). Moreover, as a medicinal plant, anise has been used as antibacterial (18,19), antifungal (3), antiparasitic (1). Moreover, previous literature showed that essential oil of anise increased the digestion of protein, cellulose and fats (20) and improved apparent whole tract and ileal digestibility of nutrients (21).

\section{Materials and methods}

A total of 120 Ross strain broiler chicks were used in this study. The birds were randomly divided into 4 equal groups with 3 replicates (10 birds for each replicates). The chicks housed in cages. Birds gave basal starter diets, after that chicks gave diets containing 4 different levels of anise seed, the first group is fed basal deficient diets (control), the second group is fed diets containing the $\% 0.3$ anise seed, the third and fourth groups were offered diets containing $\% 0.6$ and $\% 0.9$ anise seed respectively.

The experimental diets were formulated to be isocaloric and isonitrogenic according to NRC (22). Anise seed powder was gently mixed with the standard diets. The diets were prepared from 0-21 days (starter) and from 22-42 days (finisher). The ingredient and chemical composition of the rations were presented in table 1 . Also, feed and water were provided ad libitum.

Table 1: Component of rations

\begin{tabular}{lcc}
\hline \multirow{2}{*}{ Ingredients } & \multicolumn{2}{c}{ Contents \% } \\
\cline { 2 - 3 } & Starter & Finisher \\
\hline Wheat & 15 & 15 \\
Yellow corn & 45 & 47.5 \\
Soybean meal (44\% CP) & 28 & 27 \\
Protein concentrate & 8 & 6 \\
Oil & 2 & 2.5 \\
Limestone & 0.8 & 0.8 \\
Di-calcium phosphate & 1 & 1 \\
Salt & 0.2 & 0.2 \\
\hline Total Calculated chemical component \\
\hline \multicolumn{3}{c}{100} \\
\hline Crude protein \% & 21.3 \\
Metabolized energy kcal/kg & 2940 & 20.3 \\
The nutritional requirement & determined & according to \\
(NRC1994). &
\end{tabular}

The birds were kept in floor pen $1.5 \times 1 \mathrm{~m}$ broiler house containing wood shaving as litter material. Birds were vaccinated against Newcastle and Gumboro disease according to their age. Live body weight, weight gain, feed intake and feed conversion ratio (g feed/g gain) were measured at 42 days of age. At the end of the experiment, birds whose body weights were close to the group average were selected from each replicate for carcass quality measurement.

\section{Studied traits}

Live body weight, feed conversion ratio, weight gain, mortality, production index, carcass weight, carcass traits like dressing percentages, (liver, Brest, thigh, gizzard, wings, heart) weight.

Each of Live Body weight, carcass weight was measuring by electronic balance and carcass traits were measuring by these equations:

$$
\begin{aligned}
& \text { Dressing percentage }=\frac{\text { Carcass weight }(\mathrm{g})}{\text { Body weight }(\mathrm{g})} \times 100 \\
& \text { Organ Relative Weight }=\frac{\text { Organ weight }(\mathrm{g})}{\text { Body weight }(\mathrm{g})} \times 100
\end{aligned}
$$

\section{Body weight}

Birds were weighed every week as groups in each experimental unit through experimental periods by using 
(RHEWA) balance with the accuracy of $(\max =50 \mathrm{~kg}$, $\min =2 \mathrm{~kg}$ and $\mathrm{e}=100 \mathrm{~g}$ ).

\section{Feed intake}

Feed intake in each replicate was recorded and measured at the end of each week by subtracting non-eaten feed from total amount of feed supplied and daily feed intake was found by divided weekly feed intake on 7 days.

\section{Mortality percentage}

Mortality was recorded for each replication through experimental periods and calculated by this equation:

$$
\% \text { Mortality }=\frac{\text { Number of dead birds in a group }}{\text { Initial number of birds in the group }} \times 100
$$

\section{Feed conversion ratio}

Feed conversion ratio was calculated depending on the following equation:

$$
\text { Feed conversion }=\frac{\text { Feed intake }(\mathrm{g})}{\text { ratio weight gain }(\mathrm{g})}
$$

\section{Production index}

Production index was calculated depending on the following equation:

$$
\text { Production index }=\frac{\text { Average body weight }(\mathrm{g}) \times \text { livability }}{\begin{array}{l}
\text { Duration of the period }(\text { day }) \times \\
\text { feed conversion ratio } \times 10
\end{array}}
$$

\section{Statistical analysis}

All data were subjected to one-way analysis of variance within the statistical program XLSTAT (2008, version-7.5) will be used to analyze by utilizing a complete randomize design (CRD) and significant means were separated by Duncan's multiple range tests (23).

\section{Results and discussions}

\section{Effect of anise seed supplementation on dressing percentage and carcass traits}

Table 2 showed a significant $(\mathrm{P}<0.05)$ of difference between treatments on dressing percentage. The highest value of dressing percentage was resulted in $\mathrm{T} 3$ and the lower was resulted in $\mathrm{T} 1$, however there was no significant difference between $\mathrm{T} 3$ with $\mathrm{T} 2$ and $\mathrm{T} 4$, and there was no significant difference between $\mathrm{T} 1$ and $\mathrm{T} 4$.

There was a significant $(\mathrm{P}<0.05)$ difference between treatments on carcass cuts like: breast, thigh and back percentage, but there was no significant $(\mathrm{P}<0.05)$ effects on wings, heart, liver and gall bladder percentage as showed in table (Table 3 ), the highest value of breast percentage was resulted in $\mathrm{T} 2$ and the lower was resulted in $\mathrm{T} 4$, however there was no significant difference between T2 and $\mathrm{T} 3$, and there was no significant difference between $\mathrm{T} 1$ and T4. The improvement in some of the percentages of cuts this may be related to the effects of anethol on the digestive system and liver metabolism.

The highest value of thigh percentage was resulted in $\mathrm{T} 4$ and the lower was resulted in T3, however there was no significant difference between $\mathrm{T} 4$ with $\mathrm{T} 1$ and $\mathrm{T} 2$, and there was no significant difference between $\mathrm{T} 3$ and $\mathrm{T} 2$.

Table 2: Effect of treatments on dressing percentage and some carcass cuts

\begin{tabular}{ccccc}
\hline Treatments & Dressing percentage $\%$ & Breast \% & Thigh \% & Wings \% \\
\hline T1 & $64.821 \mathrm{~b} \pm 1.37$ & $37.110 \mathrm{ab} \pm 0.11$ & $28.923 \mathrm{a} \pm 0.92$ & $10.660 \mathrm{a} \pm 0.15$ \\
T2 & $69.302 \mathrm{a} \pm 1.44$ & $38.801 \mathrm{a} \pm 0.26$ & $28.439 \mathrm{ab} \pm 0.37$ & $10.405 \mathrm{a} \pm 0.21$ \\
T3 & $69.557 \mathrm{a} \pm 2.70$ & $38.121 \mathrm{a} \pm 0.14$ & $27.579 \mathrm{~b} \pm 0.45$ & $10.241 \mathrm{a} \pm 0.14$ \\
T4 & $68.839 \mathrm{ab} \pm 1.19$ & $35.540 \mathrm{~b} \pm 0.22$ & $29.161 \mathrm{a} \pm 0.47$ & $9.583 \mathrm{a} \pm 0.11$ \\
\hline
\end{tabular}

Means \pm SE. T1 $=$ control group, T2, T3 and T4 groups are supplementing $(0.3 \%, 0.6 \%$ and $0.9 \%$ ansie seed respectively). The means in the same column with different superscripts are significantly different $(P<0.05)$.

\section{Effect of anise seed supplementation on some edible and non-edible parts:}

The highest value of back percentage was resulted in $\mathrm{T} 4$ and the lower was resulted in $\mathrm{T} 2$, however there was no significant difference between $\mathrm{T} 4$ with $\mathrm{T} 1$ and $\mathrm{T} 3$, and there was no significant difference between $\mathrm{T} 3$ with $\mathrm{T} 2$ and T1. but there was no significant $(\mathrm{P}<0.05)$ effects of different treatments on some edible organ percentage like heart, liver and gizzard percentage and non-edible organ percentage such as gall percentage (Table 3 ).

\section{Effect of anise seed supplementation on live body weight, body weight gain and feed intake}

There was a significant $(\mathrm{P}<0.05)$ effect of treatments in live body weight. The highest value of live body weight was resulted in $\mathrm{T} 2$ and the lower was resulted in $\mathrm{T} 1$, however there was no significant difference between $\mathrm{T} 2$ with $\mathrm{T} 3$ and $\mathrm{T} 4$, and there was no significant difference between and T1 and T3 (Table 4).

The increase in body weight and body weight gain may be due to the presence of active material such as anethole, 
which has stimulating effects on the digestive system and the active ingredient found in the anise oil such as anethole which increases production of digestive enzymes that improved utilization of digestive products through enhanced liver function.

Table 3: Effect of treatments on some body organ percentage

\begin{tabular}{cccccc}
\hline Treatments & Heart \% & Liver \% & Gizzard \% & Back \% & Gall \% \\
\hline T1 & $0.716 \mathrm{a} \pm 0.011$ & $2.781 \mathrm{a} \pm 0.100$ & $3.577 \mathrm{a} \pm 0.045$ & $22.698 \mathrm{ab} \pm 0.100$ & $0.114 \mathrm{a} \pm 0.001$ \\
T2 & $0.614 \mathrm{a} \pm 0.014$ & $2.998 \mathrm{a} \pm 0.213$ & $3.406 \mathrm{a} \pm 0.016$ & $21.609 \mathrm{~b} \pm 0.706$ & $0.119 \mathrm{a} \pm 0.002$ \\
T3 & $0.710 \mathrm{a} \pm 0.031$ & $2.340 \mathrm{a} \pm 0.012$ & $3.562 \mathrm{a} \pm 0.023$ & $23.309 \mathrm{ab} \pm 0.360$ & $0.105 \mathrm{a} \pm 0.00$ \\
T4 & $0.713 \mathrm{a} \pm 0.019$ & $2.720 \mathrm{a} \pm 0.016$ & $2.588 \mathrm{a} \pm 0.014$ & $24.198 \mathrm{a} \pm 0.496$ & $0.069 \mathrm{a} \pm 0.006$ \\
\hline
\end{tabular}

Means \pm SE. T1 $=$ control group, T2, T3 and T4 groups are supplementing $(0.3 \%, 0.6 \%$ and $0.9 \%$ ansie seed respectively).

The means in the same column with different superscripts are significantly different $(P<0.05)$.

Table 4: Effect of treatments on live body weight (LBW), body weight gain (BWG) and feed intake (FI)

\begin{tabular}{cccc}
\hline Treatments & LBW $(\mathrm{g})$ & BWG $(\mathrm{g})$ & FI $(\mathrm{g})$ \\
\hline \multirow{2}{*}{ T1 } & $2500 \mathrm{~b}$ & $2457 \mathrm{~b}$ & $3857.7 \mathrm{a}$ \\
& \pm 20.11 & \pm 17.11 & \pm 36.43 \\
$\mathrm{~T} 2$ & $3200 \mathrm{a}$ & $3150 \mathrm{a}$ & $3417 \mathrm{a}$ \\
& \pm 16.33 & \pm 21.99 & \pm 33.32 \\
$\mathrm{~T} 3$ & $2850 \mathrm{ab}$ & $2799 \mathrm{ab}$ & $3594.8 \mathrm{a}$ \\
& \pm 18.27 & \pm 16.55 & \pm 31.12 \\
$\mathrm{~T} 4$ & $3050 \mathrm{a}$ & $3008 \mathrm{a}$ & $3483 \mathrm{~b}$ \\
& \pm 16.99 & \pm 19.48 & \pm 32.99 \\
\hline
\end{tabular}

Means \pm SE. T1 $=$ control group, T2, T3 and T4 groups are supplementing $(0.3 \%, \quad 0.6 \%$ and $0.9 \%$ ansie seed respectively). The means in the same column with different superscripts are significantly different $(P<0.05)$.

\section{Effect of anise seed supplementation on feed conversion ratio, production index and mortality percentage}

There was significant $(\mathrm{P}<0.05)$ effects of all different treatments on feed conversion ratio (FCR) The highest value of FCR was resulted in T1 and the lower was resulted in $\mathrm{T} 2$, however there was no significant difference between $\mathrm{T} 2$ with $\mathrm{T} 3$ and $\mathrm{T} 4$, and there was no significant difference between and $\mathrm{T} 1$ and $\mathrm{T} 3$. The positive improvement in average gain and feed conversion ratio in $0.3 \%$ and $0.9 \%$ groups may be related to anise active compound such as anathol and eugenol which increase body weight by destroying of the pathogen microorganism in the digestive system.

There was significant $(\mathrm{P}<0.05)$ effects of all different treatments on production index. The highest value of production index was resulted in $\mathrm{T} 2$ and the lower was resulted in T1, however there was no significant difference between T2 and T4, and there was no significant difference between and T1 and T3. Production index was significantly $(\mathrm{P}<0.05)$ improved as anise supplementation was increased. The highest index attended by supplementing $0.3 \%$ and $0.9 \%$. There was no significant $(\mathrm{P}<0.05)$ effects of all different treatments on mortality percentage (Table $5)$.

Table 5: Effect of treatments on feed conversion ratio, production index and mortality percentage

\begin{tabular}{cccc}
\hline Treatments & FCR & PI & Mortality (\%) \\
\hline \multirow{2}{*}{$\mathrm{T} 1$} & $2.1 \mathrm{a}$ & $278.57 \mathrm{~b}$ & $0.001 \mathrm{a}$ \\
& \pm 0.001 & \pm 7.30 & \pm 0.00 \\
$\mathrm{~T} 2$ & $1.7 \mathrm{~b}$ & $441.18 \mathrm{a}$ & $0.000 \mathrm{a}$ \\
& \pm 0.001 & \pm 9.44 & \pm 0.00 \\
$\mathrm{~T} 3$ & $1.9 \mathrm{ab}$ & $350.75 \mathrm{~b}$ & $0.000 \mathrm{a}$ \\
& \pm 0.002 & \pm 12.26 & \pm 0.00 \\
$\mathrm{~T} 4$ & $1.8 \mathrm{~b}$ & $397.88 \mathrm{a}$ & $0.001 \mathrm{a}$ \\
& \pm 0.001 & \pm 8.02 & \pm 0.00 \\
\hline
\end{tabular}

Means \pm SE. T1 $=$ control group, T2, T3 and T4 groups are supplementing $(0.3 \%, \quad 0.6 \%$ and $0.9 \%$ ansie seed respectively). The means in the same column with different superscripts are significantly different $(P<0.05)$.

\section{Acknowledgment}

This study was conducted at the poultry farm of College of Agricultural Sciences, University of Sulaimani. The experiment was included management and treating the birds in the farm to study the effect of supplemented anise seed powder to the diet on broiler performance, and I thank for all of Hawneaz Saeed, Banan Sabr and Dashty Ahmad for giving the helpful during this experiment.

\section{References}

1. Cabuk M, Alcicek A, Bozkurt M and Imre N. Antimicrobial properties of the essential oils isolated from aromatic plants and using possibility as alternative feed additives. National Ani Nut J. 2003;1:184-187.

2. Osman NE, Talat G, Mehmet C, Bestami D, Simsek UG. The effect of an essential oil mix derived from Oregano, Clove and Anise on broiler performance. Int J Poult Sci. 2005;4:879-884. 
3. Soliman KM, Badea RI. Effect of oil extracted from some medicinal plants on different mycotoxigenic fungi. Food Chem. Toxicol. 2002;1(40):1669-1675.

4. Afifi NA, Ramadan A, El-Kashoury EA, El-Banna HA. Some pharmacological activities of essential oils of certain umbelliferous fruits. Vet Med J Giza. 1994;48:85-92.

5. Valero M, Salmeron MC. Antibacterial activity of 11 essential oil against Bacillus cereus in tyndailized carrot broth. Int $\mathrm{J}$ Food Microbiol. 2003;85:73-81.

6. Raziq F, Khan S, Chand N, Sultan A, Mushtaq M, Rafiullah, Suhail SM, Zeb A. Effect of water-based infusion of Aloe barbedensis, Pimpinella anisum, Berberis lycium, Trigonella foenum-graecum and Allium sativum on the performance of broiler chicks. Pak Vet J. 2012;32:593-596.

7. Mushtaq M, Durrani FR, Imtiaz N, Sadique U, Hafeez A, Akhtar S, Ahmad S. Effect of administration of Withania somnifera on some hematological and immunological profile of broiler chicks. Pak Vet J. 2012;32:70-72.

8. Tripathi, SC, Shuklas SH. Antifungal substances in the essential oil of anise Pimpinella anisum L. Agr Bio Chem. 1987;51:75-98.

9. Bown D. The herb society of American new encyclopedia of herbs and their users. New York: DK Press; 2001: 7513 p.

10. Ciftci M, Güler T, Dalkiliç B, Ertas ON. The effect of anise oil Pimpinella anisum L. on broiler performance. Inter J Poult Sci. 2005;4(11):851-855.

11. Al-Neamy SB. Influence of phosphatic on seeds quantity in growth yields properties and active in gradient in anise plant [master's degree]. Baghdad: College of Agriculture, University of Baghdad; 2008. p. 45-49.

12. Kubo L, Himejima M. Anethole, a synergist of polyfodial against filamentous microorganisms. J Agric Food Chem. 1991;39:22902292.
13. Al-Dajwy A. Encyclopedia of production of medical and aromatic plants. Cairo: Madbolly Printer; 2006.

14. Langhout P. New additives for broiler chickens. World Poult. 2000;16:22-25.

15. Muzahim F. Effect of supplementation different levels of anise seeds or roselle flowers to the diet on performance efficiency of layer, Japanese quail and broiler [Ph.D. dissertation]. Baghdad: College of Agriculture, University of Baghdad; 2009. p. 8-50.

16. Hamilton A. Medical plants and conservation uses and approaches. 2003. https//www.associated/article.

17. Ozean MM, Jean LC. Chemical composition and antifungal effect of anise (Pimpinella anisum L.) fruit oil at ripping stage. J Ann Microbiol. 2006;56:353- 358.

18. Singh G, Kapoor IP, Pandey SK, Singh UK, Singh RK. Studies on essential oils: part 10; antibacterial activity of volatile oils of some spices. Phytother Res. 2002;(16):680-682.

19. Tabanca N, Bedir E, Kirimer N, Baser KH, Khan SI, Jacof MR, Khan IA. Antimicrobial compounds from Pimpinella species growing in Turkey. Planta Medical. 2003;69:933-938.

20. Jamroz D, Kamel C. Plant extracts enhance broiler performance. In non-ruminant nutrition: Antimicrobial agents and plant extracts on immunity, health and performance. J Ani Sci. 2002;80(1):41.

21. Hemandez F, Madrid J, Garcia V, Orengo J, Megias MD. Influence of two plant extract on broiler performance, digestibility and digestive organ size. Poultry Science. 2004;(83):169-174.

22. NRC. Nutrient requirements of poultry. $9^{\text {th }}$ ed. Washington: National academy press; 1994.

23. Duncan DB. Multiple rang and multiple $F$ test. Biometerics. 1955;11:1-42. 